\title{
Faux Connaître: Getting It and Not Getting It
}

\author{
HEESOON BAI, HARTLEY BANACK and CATHERINE BROOM
}

Simon Fraser University

\begin{abstract}
Borders not only limit contact and exchange but they often connect and create ways of communication and interaction. To establish and maintain both limits and contact, power must come into play. Thus borders act as a "technology of power," to use Foucault's terminology. While the Foucauldian decentralization of power from institutionalized centres does not directly comment on ethics of power, it helps us to understand better the complexity of ethical relationships that emerge from the workings of power through a myriad of borders. This panel will consider Foucauldian perspectives on how power might operate within a proposal of education with/out borders, especially as it might pertain to our Faculty of Education at Simon Fraser University. Panellists will be asked to discuss the following questions: 1) Might Foucault's works ever suggest a possibility of living without borders and limits? What is the implication of this question for an educational institution like ours? 2) What could a notion of 'without' imply in terms of a utopian dream and an epistemological negation that posits and positions power relations?
\end{abstract}

\section{A DIALOGUE ON FOUCAULT}

HARTLEY: Three people are gathered in a room on a rainy Thursday afternoon in Vancouver. A window looks out to nowhere; we can't see anything. Two single fluorescent lights illuminate us. We are the three people who participated in the Education With/Out Borders conference presentation entitled Faux Connaitre: Getting It and Not Getting It, in October 2006, and now we are going to reenact the interview / conversation to revisit some of the themes and perhaps tease-out further themes. I'm Hartley Banack, a doctoral student at SFU.

CATHERINE: I'm Catherine Broom. I'm a doctoral student at SFU and a practicing teacher.

HEESOON: I'm Heesoon Bai, and I teach in Philosophy of Education at SFU.

HARTLEY: We're going to begin with a question Heesoon is going pose on Foucault and philosophy.

HEESOON: Mine is not so much a question as a topic that we can reflect on together and discuss. I'm really interested in Foucault's notion of intellectual work and its relevance to education. I am aware that Foucault was wary about titles and labels like 'philosopher' and 'philosophy', knowing what these terms usually signify, but my own preferred understanding of 'philosophy' and 'philosopher' matches what Foucault calls 'criticism' (as intellectual work) and 'intellectual' and so I shall treat these terms interchangeably. One of my favourite quotes from Foucault comes from his anonymous interview (where he wanted to be known simply as "the masked philosopher") in which he speaks of his vision of the intellectual as a curious and awe-inspired

(C) Copyright 2007. The authors, Heesoon Bai, Hartley Banack and Catherine Broom, assign to the SFU Educational Review the right of first publication and educational and non-profit institutions a non-exclusive license to use this document for personal use and in courses of instruction provided that the article is used in full and this copyright statement is reproduced. Any other usage is prohibited without the express permission of the author. 
dreamer ${ }^{1}$. Reading these lines, I was very inspired, and thought this is what my vision of education could be. So how do you resonate with Foucault's vision, and how do you see it cohere with your own notion of education?

HARTLEY: What does that vision of philosophy mean within the current understanding of education, which is not focused around this type of inquiry or inquisitiveness with experience?

HEESOON: We must begin with an acknowledgement that individuals are having or going through experiences, and that's the most important thing in education because with this we validate their curiosity and their desire to learn and know about what they are going through as existential beings. And this sets them up as ethical beings of free and open relationship to reality. This is the starting point of philosophical inquiry and exploration.

HARTLEY: Yet, at the same time, it also acknowledges the rigidity with which we sense the world at points; that there are structures out there that either we as individuals continue to perpetuate, or that we recognize as we come upon these structures at moments in time in our journey. For me, a foundational notion for an exploratory relationship with education is the acceptance that there are structures. We come into contact with these on so many different levels, and yet, as well, we need to maintain perspective towards inquisitiveness and curiosity.

CATHERINE: Is it possible to teach something like philosophy in a very structured environment when philosophy is something you live?

HEESOON: My gut reaction is to say, "No, we cannot do it, as this is like trying to saw with a hammer and vice versa." But on second thought, what Foucault says about philosophy, as an invitation to inquire and explore, does allow and assist us in exploring this awkward and incoherent situation. This Foucauldian approach to philosophy has us confront, wrestle, and play with the structure, which coincides with the leitmotif of SFU's Education With/Out Borders Conference and Journal. This approach to philosophy does not "complain" that we have an incoherent situation and therefore we cannot do philosophy or an optimal job of doing philosophy, or that we can only do a very compromised job. Rather, here we are saying that the whole activity and practice of philosophizing is to take on structures, to problematize and wrestle with them. This is how philosophy can become a heuristic for learning to live ethically.

HARTLEY: Foucault wrote, “...there is no question that a society without restrictions is inconceivable, but I can only repeat myself in saying that these restrictions have to be within the reach of those affected by them so that they at least have the possibility of altering them."2

\footnotetext{
${ }^{1}$ I can't help but dream about a kind of criticism that would try not to judge but to bring a oeuvre, a sentence, an idea to life; it would light fires, watch the grass grow, listen to the wind, and catch the sea foam in the breeze and scatter it. It would multiply not judgments but signs of existence; it would summon them, drag them from their sleep. . . it would bear the lightning of possible storms. . . There is an overabundance of things to be known: fundamental, terrible, wonderful, funny, insignificant, and crucial at the same time. And there is an enormous curiosity, a need, a desire to know. . [Curiosity] evokes 'care'; it evokes the care on takes of what exists and what might exist; a sharpened sense of reality, but one that is never immobilized before it; a readiness to find what surrounds us strange and odd; a certain determination to throw off familiar ways of thought and to look at the same things in a different way; a passion for seizing what is happening now and what is disappearing; a lack of respect for traditional hierarchies of what is important and fundamental. I dream of a new age of curiosity. We have the technical means; the desire is there; there is an infinity of things to know; the people capable of doing such work exist." Foucault quoted by Paul Rabinow: Paul Rabinow (ed.), Michel Foucault: Ethics, Subjectivity and Truth, (New York: The New Press, 1997), xx - xxi.

${ }^{2}$ Foucault, 1997, p.168
} 
CATHERINE: He also says, "The essential political problem for the intellectual is...t that of ascertaining the possibilities of constituting a new politics of truth of detaching the power of truth from the forms of hegemony, social, economic, and cultural, within which it operates at the present time"3 So, are you seeing teacher or intellectual as transformative influence?

HARTLEY: I guess this raises some pretty pertinent questions for people in academies where we have pedagogical schools and bring in pre-service teachers doing their Bachelor's of Education and their Professional Development Programs and receiving teaching certificates. How does Foucault's sense of philosophy, and perhaps practice of education, come into play through these experiences? Is there transformation that needs to be ignited so that these individuals can then begin to conceive them? I'm thinking individuals have come through a school, a school that they know, a school they were perhaps quite successful in, and then go through Teachers' College and if there isn't this opportunity for transformation there, then where or when might transformation take place? Or perhaps, what would be the role of the pedagogical school in this process?

CATHERINE: Perhaps intellectuals could help teachers reconsider how they think about teaching and learning through philosophy. I think that one of the major influences in today's technocratic structures lies at the turn of the century where the idea arose that there was a scientific way of chopping up the curriculum. ${ }^{4}$ I'm wondering if maybe, that "chopping up" of education with the aim of rationalizing it and making it "efficient" actually took away what education really was about. Possibly we need to investigate how we think about how we design our lessons?

HEESOON: I'm reminded of Orr's terminology, 'biophilia' and 'necrophilia'. ${ }^{5}$ I find them useful in checking out the state of wellness with respect to what we are doing in education. Biophilia, literally, is love of life; necrophilia is love of death. In the context of education, I would say that necrophilia is about our tendency to kill what is alive in us and around us through the kind of intellectual work that disconnects the individual from his or her living core of experience. To me, the prevailing objectifying agenda of scientific and technological structuring and management of learning is really necrophiliac.

CATHERINE: Is that what Dewey was trying to say when he said that school is life? And school and education are experience? Is that what he was trying to get at?

HEESOON: Yes. I think there is an intersection between Dewey and Foucault, and for that matter, with A.N. Whitehead, too, who also reminded us that there is only one subject for education, which is Life. In fact, the criticisms people have, and I have, too, of Dewey, are due to his overzealous endorsement of science and its objectifying approach to life and learning.

HARTLEY: In terms of the juxtaposition between, perhaps, biophilia and necrophilia, a sense of death seems to be connected to overstructuralization of perception and experience. We see this often in education. As we continue to structuralize curriculum, we believe in curriculum that is fundamentally fixed and rigid. Thus we move towards necrophilia, death and love of death, where we interact with things in a way as if they were 'still life'. On the other side, there is the possibility for creativity, or generative experience. But really meaningful experience, where emotions are heightened and you feel a sense of connection with world as experience, is quite limited in the overstructuralized emphasis received through institutions, received through

\footnotetext{
${ }^{3}$ Foucault, 1980, p. 192

${ }^{4}$ American social efficiency experts like Bobbitt and Snedden in the United States, argued that education was something you could cut up into a series of steps, where you had your objectives laid out for which you then determined the steps to reach those desired aims, in like fashion to Taylor's scientific management theory for increasing the productivity of industrial processes. You can see this change in the curriculum as this idea of scientific curriculum making comes into effect in $\mathrm{BC}$ in the 1930s.

5 Orr, 1994.
} 
curricularization, received through classroom management, and so many other forms of control that Foucault speaks of.

CATHERINE: I hear the idea that forms of knowledge and power are embedded together; that they are tied in with curriculum and structures we see in schools. Supposedly "scientific" curriculum is a power knowledge structure. From a Foucauldian perspective there is always a connection between power and knowledge, so one can wonder how much the school has been used to push one particular form of knowledge. Do we ever question that curriculum is a knowledge form with power associated with it as well?

HEESOON: In this context, we can bring in Foucault's distinction between knowledge and truth as: "a readiness to find what surrounds us strange and odd; a certain determination to throw off familiar ways of thought and to look at the same things in a different way; a passion for seizing what is happening now and what is disappearing; a lack of respect for traditional hierarchies of what is important and fundamental. .." This readiness, determination, and passion are our orientation towards and demeanor of truth-seeking. Knowledge is oriented towards what's known, certain, legitimated, and gives us power and control; truth in the way Foucault uses that word marks the opposite orientation. Applied to education, we can see schooling is predominantly about knowledge acquisition and not truth-seeking.

HARTLEY: Structuralization seems like it is emerging in so many different ways. Foucault notes three: self, others and things — and clearly outlines how mutually dependant these three always are 6 . This allows for confluence of some of the larger energies that we sense in our experience as we go through the world: energy of power, energy of ethics and energy of self-knowledge.

CATHERINE: Thinking of transforming or transformative education, we need to be aware of unconscious structures that shape how we think, and Foucault tries to make this explicit. Unconscious structures are all of those things we take for granted but we don't even see because they're so embedded in the way that we live. I think that is how he views power as well: that it's not just a top-down structure but it's everywhere. He describes, "By power...I do not understand a general system of domination exercised by one element or group over another... what needs to be understood is the multiplicity of relations of force that are immanent to the domain wherein they are exercised, and that are constitutive of its organization; the game that through incessant struggle and confrontation transforms them, reinforces them, invents them; the supports these relations of force find in each other, so as to form a chain or system, or, on the other hand the gaps, the contradictions that isolate them from each other; in the end, the strategies in which they take effect and whose general pattern or institutional crystallization is embodied in the mechanisms of the state, in the formulation of the law, in social hegemonies." I I would add to this: in education, too!

HARTLEy: Yet we seem to be addicted to the idea of central points, so we're able to identify these points or they're easily identified for us: the school, the principal, the class, the students. We have very clear senses and we can speak conceptually around these 'things'. As with many addictions, they address some need for comfort, so one feels secure in returning to something that somebody knows in some sense, even if not absolutely, but there is enough familiarity with them that there's no urge to go beyond and explore discomfort. This allows for a certain superficiality of interaction around 'things' because in reified structures, we can speak about them as if these ideal forms exist and say "Yes, education is this, teaching is this, students are students." This creates an economy, a currency that then offers a bunch of possibilities for perpetuating structuralization through addiction. As with addiction, one shows a tendency of not necessarily recognizing

6 “...practical systems stem from three broad areas: relations of control over things, relations of action upon others, relations with oneself. This does not mean that each of these three areas is completely foreign to the others. It is well know that control over things is mediated by relations with others; and relations with others in turn always entail relations with oneself, and vice versa. But we have three axes whose specificity and whose interconnections have to be analysed: the axis of knowledge, the axis of power, the axis of ethics." Foucault, 1997, p.318-319

${ }^{7}$ Foucault, 1981, p.121 
one's addiction; of not knowing you're addicted to something and in that there are dangerous tendencies to continue on without the possibility for reflection as offered in Foucauldian philosophy.

HEESOON: Very illuminating! What you're saying about addiction resonates with Foucault's distinction I was referring to earlier between knowledge and truth. I would say that addiction means that one is not seeking truth. The above mentioned way of speaking of truth is highly unconventional. Conventionally, truth means what is the case in the world independently of one's subjective perception and interpretation. This way of conceptualizing truth leaves out or leaves little room for the individual's relational openness to reality. Conventional understanding of truth makes knowledge acquisition the business of 'getting it right' with respect to reality. So, when we tell students what is right and what is wrong, what is true and what is not—in other words, the usual business of knowledge transmission-what we are doing is guiding and fixing their perception of reality so that they see reality in particular ways and don't explore other ways of seeing. This is what control is about. We do not allow individuals to question and problematize their relation to reality, and to dream and explore other ways of seeing.

CATHERINE: Uh-hmmm. Yes. I sort of see it as being embedded in the word "tradition". And a lot of things that are tradition only became so by accident or by convenience, but then, over time, they became "truth", and they became accepted ways of doing things. There's a wonderful paper written about the curriculum where the author describes a curriculum developed during the saber-toothed tiger time of man when teaching youngsters how to hunt was necessary and practical knowledge and became embedded as "truth," so that hundreds of years later, after that particular society had died away, teaching this form of saber-toothed curriculum remained ${ }^{8}$. In looking at the idea of tradition these ritualized practices mask as truth.

HARTLEY: Yes, there's a component of historicity that mutates over time or continues through time. But let's consider a young teacher or a pre-service teacher coming into a pedagogical school. You've been accepted as a teacher, you've now been told you are going to become a teacher and you've adopted, in some sense, a certain identity, a certain mind-frame - which, again, is a structure of what a teacher 'is.' As you're approaching that and coming through that, there's a lot of confrontation one has to deal with and learn to navigate in this novel experience. Things from: How do you physically find the classroom? To: How do you interact with students and the curriculum? What Foucault proposes in his philosophy provides or provokes a high degree of discomfort, a lack of confidence, and insecurity. In terms of having somebody train to become a teacher, how can the facilitators of that process support: 1) that discomfort of the novelty of this experience for this neophyte, and 2) work towards instilling this hopefully transformative approach towards themselves and their interaction with education?

CATHERINE: What you're asking people to do is to question what it is to be a teacher whilst trying to become a teacher. That's very difficult to do. It seems related to Foucault's thoughts of deconstructing through questioning. Could you talk about that?

HEESOON: Foucauldian teacher education is not possible, is not practicable, without creating an environment that nurtures and supports student teachers going through difficult and even painful processes of transformation wherein they have to disassemble themselves, which is a very vulnerable thing to do. How could our students take risks and fall apart before us (so that they can re-assemble themselves) if we are in the position of passing judgments and grading them -sorting them to show who shall survive and thrive, and who shall perish? Recall Foucault's line about the sort of criticism that would "multiply not judgments but signs of existence"? We don't do this kind of criticism well in the academy, even in teacher education.

HARTLEY: It's almost therapeutic.

\footnotetext{
8 See Peddiwell, J.A., 1959, The Saber-Toothed Tiger Curriculum.
} 
HEESOON: Foucault talks about ascesis: Ascesis is "the work that one performs on oneself in order to transform oneself or make the self appear which, happily, one never attains." All profound learning, insofar as it is undertaken voluntarily, is ascesis. All profound education, insofar as it intends to support the process of ascesis, must be one of tremendous care, nurturance, and support. Here is Foucault again: "I insist that this change takes the form neither of a sudden illumination that makes 'the scales fall from the eyes' nor an openness to every movement of the time. I would like it to be an elaboration of the self by the self, a studious transformation, a slow and arduous transformation through a constant care for the truth." So, as I imagine what teacher education would be like, the first thing that comes to my mind is how the kind of intellectual culture of criticism we have in the academy and school in general is not one that can support Foucauldian life-supporting, biophilic ascesis. In fact, what I see is the necrophilic pressure against which students armour themselves. They see that they cannot afford to go to pieces, fall apart, and make themselves vulnerable to the judgment of failure and loss.

CATHERINE: That's not just teacher education but tied into processes of schooling, such as grading. Do grades disassemble us? Are they helping students grow, question and develop themselves? I don't know if they are. I think they're helping to select certain students to be seen as "successful", while others are excluded. It's a process of disassembling in terms of destroying some students' confidence, rather than giving them an education where they're given tools and knowledge to "prepare them for life".

HARTLEY: As we're thinking of the word grade, perhaps we should consider gradient and graduated and all the cognates related to grade, how that constellation relates to structure and structuralism. What we hear is so fatal. Deadening! How one, at such a young age, is indoctrinated into this culture of striving towards structure, grade, graduation; whereas ascesis I sense as care perhaps versus this judgment in school as distinction, but there's also a fundamental relationship to time and process over time. Clearly this is not an "I've seen the light and I am now other," but an arduous, long process that occurs gradually -in a different sense of gradual, one no longer of structural telos aimed at; now reconceived, the telos is...

CATHERINE: ...Embedded in the process.

HEESOON: And only the individual who's granted freedom can undertake it.

CATHERINE: This idea of grades is part of the industrial school established in turn of the century America when mass schooling developed. ${ }^{10}$ Interestingly, most of the students who did well came from white, middleclass backgrounds and it was assumed that they were more intelligent. It wasn't considered that perhaps the test was flawed. This process of scientifically streamed standardization predetermined the life paths of many students. Many of these early structures, such as grades, are still embedded, sometimes unseen, in school today.

HARTLEY: Foucault speaks a lot about abnormalcy - normal versus abnormal. And in this sense of abnormal there is reference to self-discipline ${ }^{11}$. In disassembling self, how might that process initiate when self, as student, is perpetually bound to similar expectations? Trust is not something one is willing to expose (i.e. put forth, rely on, risk, or wager), especially in a public realm. How might that disassembling of self begin

\footnotetext{
9 Foucault quoted by Paul Rabinow: Paul Rabinow (ed.), Michel Foucault: Ethics, Subjectivity and Truth, New York: The New Press, 1997), xx xvii.

10 Snedden was particularly important in developing the idea of grades and designing "efficient" school structures. He believed that the mass of students were cattle, with a few "good" ones thrown in, and so he argued for a selective curriculum where you would use standardized tests, because these were obviously right, to determine the selective schooling paths and thus the lives of students, based on how their results.

${ }^{11}$ Foucault writes of self-discipline as a process of internalization whereby the external norms become so internalized that one perpetuates (and values) these subconsciously. See Discipline and Punish for a full elaboration.
} 
to take place? I see this as a chicken-egg type of conundrum - the educator, trained in the pedagogical school, has lived a school experience as a child; this is what they know, who they are; in the classroom they perpetuate this. Student moves to become educator- endlessly. Where is the moment, break, to insert, create, transform?

CATHERINE: One transformative means is philosophy. Taking time not just to study what philosophy is, but discussing all embedded, invisible structures such as evaluation. When I was a student teacher, I just wanted to get the practicalities of being a teacher: How do I make my tests, how do I make my lessons? How does the school work? I was very interested in those structures. I was a typical student teacher. It took many years of teaching to start looking at myself and questioning what I thought, and realizing it was my philosophy that had affected how I interacted with students and taught that philosophy is probably the most important subject in a teacher education program. That's through my own lived experience.

HARTLEY: [laughs] I sensed a certain ambivalence with my teacher education experience where, on the one hand, there was this strong urge to get maximum worth, to really feel like we were going to be prepared or, armed for the task ahead. On the other hand, there also was a certain disposition towards really exploring what one's self might mean to one's self - how that Self might come into a classroom and interact with all these other Selves in an educational or transformative process. With the hurry of the program, there isn't time for what's described in the program.

CATHERINE: I have two comments: 1) with time, the teacher education experience increases in value, and 2) if philosophy is experience, maybe you need to have experience teaching before you can dissemble it and make the process conscious?

HARTLEY: Shifting the discussion a tad, can we talk for a while about borders? The conference we presented at was called "Education With/Out Borders." It's a provocative title for a conference. When Foucault's writings are considered, there's a lot of fertile ground for exploration. The sense of a border existing or not existing immediately offers constructs: the practice of education, the practice of schooling, the practice of teaching. How do you think Foucault might respond to a conference framed with the title "Education With/Out Borders"?

CATHERINE: Foucault views borders as one, so power relations are never fully dominative, nor escapablethey are more like a spider's web. They extend in multifarious directions, but are always full of holes, as the spaces or boundaries between borders. These are escape routes where power/knowledge can't maintain control. There's chance to transform power/knowledge webs by escaping through holes between the structured power/knowledge you are in, although you'll always be caught in another. This gives a possibility of transformation, while raising an interesting question: are there better power/knowledge frameworks, where one would want to escape from one type into another?

HEESOON: Certainly. Returning to the Foucault quote from the beginning - talking about yearnings for different kinds of intellectuals or philosophers who support love of life in people and help open one's own core of freedom - telling which power/knowledge frameworks are better comes down to seeing how a certain approach to knowledge and power furthers vitality and love of life - biophilia - in people, and helps exercise, as freely as possible, their freedom.

HARTLEY: Foucault says, “...a system of constraint becomes truly intolerable when the individuals who are affected by it don't have the means of modifying it. This can happen when such a system becomes intangible as a result of its being considered a moral or religious imperative, or a necessary consequence of medical science." 12 Liberation seems to have possibility in a web. Perhaps an approach to 'the better system' would

\footnotetext{
12 Foucault, 1997, p.148
} 
be recognition of how power operates: that power is not solely in the teacher, in the school, in the curriculum; and to include notions of power in the regular interaction of what pedagogues do with students.

CATHERINE: Yes, structures as constructs--these affect our lived philosophies. We need self-awareness for transformative questioning of structures. Philosophy is lived. Power is something that is lived, but it's a constructed lived. If you construct a different definition or a different lived interpretation, you live a different world.

HARTLEY: Foucault writes, "Rather than arguing that rights are fundamental and natural to the individual, we should try to imagine and create a new relational right that permits all possible types of relations to exist and not be prevented, blocked or annulled by impoverished relational institutions."13

CATHERINE: Yes. There is a wonderful and positive "power" that we have, that we may not see: there is positive possibility. Foucault says, "I set out to grasp the mechanisms of the effective exercise of power, and I do this because those who are inserted in these relations of power, who are implicated therein, may, through their actions, their resistance, and rebellion, escape them, transform them...my entire research rests on the postulate of an absolute optimism..."14. A wonderful transformative possibility exists in each personindividual and teacher- through critical self-awareness that deconstructs in order to reconstruct.

HARTLEY: And an empowerment, by the quote that you've just read out, with respect to resistance, escape and transformation. As power moves through us all, as a possible generative force, can it too emanate from the individual outward, penetrating into institutions as well?

CATHERINE: There are people who take power and transform environments - both for good and bad. Foucault's philosophy emerges through having been born in France in 1926 and having lived through German occupation during World War II. Early on he was exposed to the Nazis' use of force and rhetoric, which we could call 'knowledge', to establish power. Simultaneously, he lived the opposition to this enforced power through underground resistance movements. He also lived through the student riots of the 1960s. He came to understand that power can be taken and used in transformation, for good or bad.

HARTLEY: Yet Foucault eventually left France. Some suggest he felt that there wasn't the environment in France to realize himself. What might this say for the possibility of students in classrooms, for teachers in education systems? Are there moments when radical change needs to take place? Is there a certain amount that individuals are able to resist and then need to push in other directions?

CATHERINE: Let's return to ideas of self, "How much of one's self is self or construct?" There are many ways people are constructed through labels they have been given. Recall Elliot's 'Blue Eyes/Brown Eyes' study ${ }^{15}$; not only did this transform how the students saw themselves over the period of that year, but over the period of their lives as students. I always keep this in the back of my mind when I see students, and I tell my students that story as well. I always try to get them to see how they see themselves and how the ways that they see themselves may be multi-layered constructions, formed by ways they've been treated by their parents, friends, family and school teachers. I try to make them believe in themselves. I try to provide them with opportunities to transform constructs that they have about themselves.

\footnotetext{
${ }^{13}$ Foucault, 1997, p. 158

14 Foucault, 1980, p. 193

15 "In the wake of the assassination of Martin Luther King, Jr., Elliot developed a simple exercise that explored the nature of racism and prejudice. Elliott's method for exploring racism in the context of an all-white classroom consisted of dividing her students into two groups on the basis of eye color, blue or brown (those with other eye colors were assigned to the group that most closely matched their own.)" from http://en.wikipedia.org/wiki/Jane_Elliott.
} 
HEESOON: I still have quandaries about grading. The whole business goes against the philosophy and practice of valuing and supporting students' unique individual growth and transformation. Let's not confuse grading with qualitative feedback that can support growth and transformation

CATHERINE: They don't have to get a 'C' right? Because you open the possibility for change. I think every student has the potential to do well, but often they don't do well because they don't believe inside themselves that they can. And if you help them believe in themselves-if you help to transform their own self-constructs, that they can do well, then they do do better. But I agree: grading is difficult. If you're dealing with a class where you have a provincial exam at the end, where students are going to be tested on certain factual knowledge, then it's more difficult. I still believe that you have to show that you care. By helping students - and I'm talking about the students that don't feel good about themselves as students - to reconstruct the way they see themselves as students, and by helping them to believe in themselves, you open new possibilities to them. Isn't that what we're trying to do through education?

HEESOON: Oh, I don't disagree with you about caring teachers helping students to feel good about themselves. However, I just don't see that grading sits well with the educational commitment to furthering individuals' unique and particular growth as human beings. Grading is an exercise in comparative evaluation: who is doing better than whom. Sure, you could encourage everybody in the same way. Still, grading has the ultimate objective of rewarding some people and punishing others. By grading we divide those who will succeed from those who will fail. If I were a teacher teaching young children, I don't think I could practice grading them without feeling sick. I can barely cope with grading in a graduate class. At least there, I can discuss how grading works, what kind of game they are required to play, and how they may be prepared to play it.

HARTLEY: Grades are a structure out there and when we speak about grading, and the whole process of evaluation, we can't do so without objectifying into a structure what is the task. We talk about the work, the task, norms; ways that externalize - ingrain and create - as if there were this disconnected or unattached knowledge that one approaches and in that approach we are able to produce a gradient of just how close one got. Returning to Foucault's philosophy, one recognizes the challenge that structures and barriers constantly bring to oneself and one's community. Whether it be the classroom of the school, the sports field, or the job place, we seem to create tasks that exist as if they were structures.

CATHERINE: In a Foucauldian sense, can we go around and through the porous and webbed nature of structures and give students a chance for transformation by helping students feel good about themselves and believe that they can do well? I think that it really does make a difference.

HARTLEY: And I appreciate what you're talking about; however, the position you're talking from is one that's constantly bound to a system and a certain configuration within a system, and do we need to continually create legitimization for ourselves and our students? Do we need to have that constant reminder that there is this game that is going on? We all play it even though we try to analyze and decode it, and yet we are trapped in it.

CATHERINE: In Foucault's terms: we are not trapped. Power/knowledge is such a webbed and porous structure that it provides the possibility for weaving through and transforming it. I don't think you ever have to be trapped.

HARTLEY: Again, I would respond by recalling that Foucault left Paris because he felt it intolerable.

CATHERINE: You've given up if you do that. Then you have no power because you have given up your belief in your ability to transform, and you have, therefore, given up your transformative power. I think you need to have optimism and you need to believe that there are those holes and those spaces through which 
you can move and transform. Transformation will come from your own actions. I wouldn't say he gave up France. I would say he went through the webbed nature of power/ knowledge into one better suited to him.

HARTLEY: Can we accept the same types of decision, from our students in our classrooms? At what point would we acknowledge this from a six-year-old who recently began Grade One? Would we consent to this from an eighteen-year-old in Grade Twelve who comes and renounces the system, a student who perhaps knows a pedagogue who is very caring and permits a certain amount of ability for transformation, but yet this student still feels it is insufficient? Do we have space within our system for that?

CATHERINE: In order to be able to transform and rebel, we need to be aware of what it is that we are rebelling against. We need to know the system we are trying to transform. And that takes experience.

HEESOON: When my two children were young, I was perhaps considered by others to be "extremely" protective. To me, I wasn't extremely protective. I just didn't want to subject these young and defenseless children to grading. I waited until they gained sufficient self-protection of some kind and the ability to negotiate the structure before they were released to confront the potentially damaging practice. Look how someone like Foucault, who had an enormous capacity to take on the force and negotiate, someone with all kinds of intellectual and emotional capital, giving up the resistance and fight, and moving to other countries to seek out better opportunities to further his growth.

CATHERINE: I understand the love that you have for your children and your desire to protect them. But my feeling is that if you protect them by keeping them in ignorance, by hiding them from structures of society, you do them a disservice because they're not aware of those structures. The best thing is to bring them up with a questioning awareness of structures. I think the second point I would add is: are you generally an optimist or are you generally a pessimist? And while I see many problems, challenges and difficulties with structures, I prefer to take the optimistic stance because we are looking at things that are constructed, a web porous in nature through which one can transform, reconstruct selves and our own understandings, to take power and to bring change.

HARTLEY: I sense it's not either-or, optimism or pessimism; it's a constant shifting of play.

\section{HEESOON: Negotiation.}

HARTLEY: Yes, negotiation back and forth between what's coming at you, what's coming out of you. It's so complex that I can't necessarily say I would ever identify myself as either an optimist or a pessimist in an overall sense. But that flux, that play, that flow that exists between those is the richness of being human in culture and being exposed to these structures that seem so pending and dominant, and yet also sensing possibility - whether that possibility be absolutely dismal or tremendously liberating. I also sense that it's the conversation that ensues, that constant conversation around experience that permits the fear one might have of exposing a child to structures that perhaps they're not ready for. That concern can be addressed in this conversation. Continuous sense-making of the child begins at such a young age, just as children learn to speak without any support, they are able to enter into life processes as well, as you say Catherine, and that is very powerful.

CATHERINE: I'd see the comment that you've just made as a very optimistic one. And maybe instead of optimism and pessimism, instead of seeing two opposites, maybe we could go back to Heesoon's comment on life and death. How do you live? Do you live alive?

HEESOON: All this comes back to the notion of freedom that Foucault centralized. You have to give children or students freedom to experience and to negotiate. So when they say, "Mother (or, Teacher), I'm not up to negotiating this path, this grading system today or this year," I have to accept and support that. They have to be given the freedom to hide. This is an example of negotiation we're talking about. To me the 
sense of optimism is commensurate with the sense of power and agency. For me there was always the question: is my child (or student) ready to go and stand up against the structure and its coercive power, and negotiate?

CATHERINE: You can't forget the other part of the equation, in terms of children, and bringing them into our society: power always equals knowledge. We can do a lot to develop that knowledge, in terms of awareness.

HARTLEY: Because there is such disjunction between family and classroom, there also needs to be exceptional attention from the classroom pedagogue. If the teacher is aware of these types of dilemma, s/he can help mediate and negotiate these for/with families, because as a family: 1) you are not necessarily steeped in education or schooling, and 2) you are perhaps very new to being a parent and have apprehension around the relationship between schooling and family. It seems this is perpetuated, unmediated. This can create a schism for the child who perhaps receives mixed messages between a teacher who promotes a certain type of exploration of self and possibility, and a home life that understands schooling as being a very structured, and perhaps, necrophilic activity.

CATHERINE: Perhaps we could say this questioning opens up the possibility of change and transformation, because in questioning, holes in the web are visible.

HEESOON: Right on! The activity of questioning makes holes in the structure, to speak metaphorically.

HARTLEY: Is that something that young families coming into the school system are prepared for? In order to create a culture of questioning, of philosophy as described by Foucault, there is a need for the pedagogue to play a fundamental role.

CATHERINE: The parents' approach is key. There are many parents, with very different actions and philosophies. Some believe schooling should be like what they had and that's why they pull their children out of public schools and put them into back-to-basics traditional schools. I would say there needs to be questioning on the part of parents about what education is. Is education sitting in rigid rows and being drilled on reading, writing, and arithmetic? I think many parents are living structures they are not questioning. Parents have great intentions for their children and want them to be successful. The way this society has conceptualized success is embedded in invisible structures. Is getting an A necessarily success? Well, unfortunately, in some ways yes, it is because that A is your ticket to university, which is your ticket to most professional jobs. It's embedded in structures.

HARTLEY: The disassemblage Foucault refers to cannot exist solely in the self. People will not be successful if this is not supported throughout community. To have a child come into a classroom that might operate in a Foucauldian philosophical manner, and then return to a home where the family or parents literally beat the crap out of the child when they are out of line, that creates a schism for the child that perhaps further entrenches a child into self-protection and self-vigilance which are some of the structures and technologies that Foucault identifies for the self. These things are always connected just as power is webbed and linked, and connected as well to all of our communal relationships.

HEESOON: Yes, indeed. At the end, we are looking at enormous complexity - mind-boggling, staggering complexity, which leaves you in bewilderment. It takes courage to face reality, and keep on going in your quest for Foucauldian truth. 


\section{Acknowledgments}

This paper was originally offered as a dialogue/panel presentation at the 2006 SFU Faculty of Education, Education With/Out Borders conference. While the original presentation included much audience participation, we wish to acknowledge that audience, who in diverse manners remains present and embedded in this instantiation.

\section{References}

Foucault, M. "Power/Knowledge". Selected Interviews \& Other Writings 1972-1977 Edited by C. Gorden. New York: Pantheon Books, 1980.

Foucault. M.. History of Sexuality Volume 1. London: Penguin, 1981.

Foucault. M. Michael Foucault: Ethics, Subjectivity \& Truth. Edited by P. Rabinow. New York: The New Press, 1997.

Orr, D. Earth in Mind: On Education, Environment, and the Human Prospect. Washington: Island Press, 1994.

\section{About the Authors}

Heesoon Bai is an Associate Professor in Philosophy of Education in our Faculty at SFU (hbai@sfuca). Hartley Banack is a Doctoral Student with the Faculty of Education at SFU (hbanack@sfu.ca). Catherine Broom is a Doctoral Student with the Faculty of Education at SFU and a secondary school teacher in North Vancouver (cbroom@sfu.ca). 